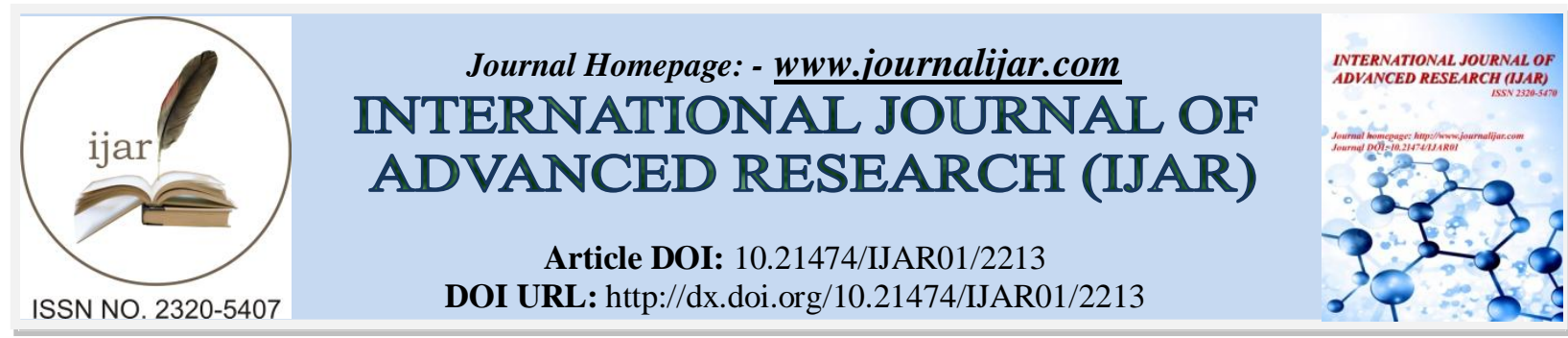

RESEARCH ARTICLE

\title{
ENUMERATION OF MICROBIAL LOAD IN LEAFY VEGETABLES GROWN IN PERIPHERY OF ALLAHABAD DISTRICT, UP, INDIA
}

1. Research Scholar, SHIATS, Allahabad, UP, India.

\section{Pravisha Pandey ${ }^{1}$ and Neeru Bala ${ }^{2}$}

2. Associate Professor, SHIATS, Allahabad, UP, India.

\section{Manuscript Info}

Manuscript History

Received: 28 September 2016

Final Accepted: 30 October 2016

Published: November 2016

Key words:-

Green leafy vegetables, Allahabad district, Total bacterial counts, Total Coliform, Escherichia coli, Yeast and Mold count, Salmonella spp., Shigella spp., Staphylococcus aureus.

\section{Abstract}

Leafy vegetables can become contaminated with microorganisms capable of causing diseases in human being. Leafy vegetables may be exposed to many sources of contamination like contaminated sewage used in watering the fields, where these vegetables are grown. In the present study the samples of fresh leafy vegetables like Soya leaves/Dill (Anethum graveolens L.) and Fenugreek leaves (Trigonella foenum - graecum L.). Spinach (Spinacia oleracea L.) were collected from four places of Allahabad District, namely Phaphamau, Mundera, Naini and Jhunsi area where sewage water was used for irrigating the leafy vegetables. The control site was selected in Naini area, where one vegetable grower was using the fresh ground water for irrigation, but the all the environmental condition was same as other sewage irrigated study sites. Total aerobic bacterial counts, total coliform, yeasts and moulds count were enumerated. Presence/absence of Escherichia coli, Shigella spp., Staphylococcus aureus, and Salmonella spp., in selected leafy vegetables were also identified. Most of the vegetable samples were found to be contaminated. The highest total bacterial count was found in Spinach $(8.5 \mathrm{log} \mathrm{cfu} / \mathrm{gm}$.) for Naini area and the lowest in Fenugreek leaves (4.27 log cfu/gm.) for Phaphamau area. While the total bacterial counts of the leafy vegetables grown in fresh water were $0.15 \log \mathrm{cfu} / \mathrm{gm}$. for soya leaves, $0.2 \log \mathrm{cfu} / \mathrm{gm}$. for Fenugreek leaves and $0.19 \mathrm{log} \mathrm{cfu} / \mathrm{gm}$. for Spinach. The highest Coliform counts were found in Spinach (4.36 log cfu/gm.) for Mundera area and the lowest in Soya leaves (1.3 log cfu/gm.) for Jhunsi area. While yeast and mould counts were not detected in fresh ground water grown leafy vegetables. The presence of E. coli was identified in Soya leaves and Fenugreek leaves for Naini and Jhunsi area and in spinach for all the study sites whereas it was found to be absent for Phaphamau and Mundera area in Soya leaves and Fenugreek leaves. The presence of Shigella spp. was identified in all leafy vegetables for all the study sites. Salmonella spp. were present in Soya leaves for only Naini and Jhunsi area, in Fenugreek leaves its presence was isolated for all the study sites except Phaphamau but its presence in Spinach was identified for all the study sites. The presence of Staphylococcus aureus was identified 
in soya leaves only for Naini and Jhunsi areas, in Fenugreek leaves it identified for all the study sites except Mundera

area while in Spinach its presence were identified for all the study sites. No microorganisms were present for control site where fresh ground water was used for irrigation of leafy vegetables.

Copy Right, IJAR, 2016,. All rights reserved.

\section{Introduction:-}

The fast urbanization cities have resulted in an increase in food demand for market gardening productions (Temple et al., 2005; David-Benz et al., 2005). Vegetable production offers a significant opportunity by providing employment for the poor people (Schilter, 1991; Adebooye and Opabode, 2004). Vegetables and fruits are fully recognized for their benefits towards healthy living, by their protective properties against cancer and other chronic degenerative diseases such as cardiovascular diseases and diabetes (Ragaert et al., 2004; Amitabha, 2005; Idogun et al., 2008; Heber, 2004). The daily fruit and vegetable intake of $400 \mathrm{~g}$ to $600 \mathrm{~g}$ is recommended by the World Health Organization, Food and Agriculture Organization of the United Nations, and the World Cancer Research Fund (Pollard et al., 2009). Most of raw vegetables are normally consumed without being cooked, so the possibility of food poisoning exists (Aycicek $\boldsymbol{e t}$ al., 2006). Unfortunately, the increase in consumption has been correlated with an increased frequency of outbreaks of illness associated with raw fruits and vegetables (McMahon and Wilson, 2001; Bhagwat, 2004). Previous investigations have shown that efficacy of washing and sanitizing treatments reduce microbial populations on fresh vegetables (Gil et al., 2009; Alvaro et al., 2009). In the developing countries the diarrheic diseases of food or hydrous origin kill 2.2 million people annually (FAO, 2007). The incidence of these diseases has increased, despite the introduction of preventive quality systems such as the HACCP concept and the promulgation of regulations in food safety (Nguz et al., 2005). Frequent food born diseases have been reported in India, following the consumption of vegetables. The purposes of this study was to evaluate the microbial quality of three vegetables among those commonly consumed and moreover to find out the disinfecting agents used by households to treat vegetables. A number of studies have shown that irrigation water is a potential source of microbial contamination to vegetables (Islam et al., 2004; Steele and Odumeru, 2004; Stine et al., 2005; Fonseca 2006). Surface waters are much more susceptible than ground water to microbial contamination (Steele et al., 2004).

The essential element of healthy diet is cooked or uncooked vegetables. Throughout the process of planting to consumption, vegetables can become contaminated with different pathogens such as enteric bacterial, viral and parasites. The extent of contamination depends on several factors that include, among others, use of untreated wastewater and water supplies contaminated with sewage for irrigation, post-harvest handling, and hygienic conditions of preparation in food service or home settings. But they have a protective effect against diseases.

The oral route is the most common and the most important way of human infection to different pathogens. In addition different egg parasites can attach to vegetables such as spinach and other leafy vegetables and do not leave with simple disinfection and in some cases may cause serious illness. Also various bacterial infections such as Salmonella and Vibrio cholera are the main cause of diarrhea especially in summer and detected in these vegetables. In a study in Ghana, the salad vegetables were contaminated with, Streptococcus faecalis, Salmonella typhi, Shigella and Pseudomonas. The aim of this study was to identify the types of microbial load in leafy vegetables present in the periphery of Allahabad District of Uttar Pradesh.

\section{Materials and materials:-}

\section{Selection of study site:-}

Allahabad is one of the south-eastern and among the largest districts of Uttar Pradesh, situated at the confluence of three rivers - Ganga, Yamuna and the invisible Saraswati. The meeting point is known as Triveni and is especially sacred to Hindus. It lies between the parallels of North latitudes $24^{\circ} 47^{\prime}$ and $25^{\circ} 47^{\prime}$ and East longitudes $81^{\circ} 09^{\prime}$ and $82^{\circ} 21^{\prime}$ longitudes and is surrounded by the districts Pratapgarh and Jaunpur in north, Varanasi in east, Kaushambi in west, Mirzapur and Rewa of Madhya Pradesh on the south. The total geographical area of this district is $5482 \mathrm{Sq}$. $\mathrm{Km}$. and a population of 5959798 as per 2011 census.

Periphery of Allahabad District namely Naini, Jhunsi, Phaphamau and Mundera were selected purposively for the present study as they are peri-urban areas, use of water for irrigating the vegetable crops from tanks, part of the city 
drainage system that drain untreated and partially treated domestic sewage and industrial effluents from a number of small scale units. The control site was selected in Naini area where one vegetable grower was using the fresh ground water for irrigation but the all the environmental condition was same as other sewage irrigated study sites.

\section{Collection of samples:-}

Fresh leafy vegetable samples were collected in triplicate form. The sample collected includes Soya leaves/Dill (Anethum graveolens L.), Spinach (Spinacia oleracea L.), and Fenugreek leaves (Trigonella foenum - graecum L.).

\section{Microbial analysis:-}

\section{Enumeration of total aerobic bacterial count:-}

Total aerobic bacterial count was done on Tryptone Soya Agar medium, $25 \mathrm{gm}$. of leafy vegetable samples were added to $50 \mathrm{ml}$. Butterfield's Phosphate Buffer and washed in it for about 5 minutes further serially diluted the sample in Butterfield's Phosphate Buffer, appropriate dilutions were spread on Tryptone Soya Agar plates in triplicates. All plates were incubated at $37^{\circ} \mathrm{C}$ for $24-48 \mathrm{hrs}$. Colonies in each plate were counted, averaged and expressed as log cfu/gm.

\section{Enumeration of total coliform:-}

Total coliform was enumerated using Violet Red Bile Agar medium, for enumerating the total coliforms; appropriate dilutions were prepared from samples as above and were spread plated on to Violet Red Bile Agar plates in triplicates. All plates were incubated at $37^{\circ} \mathrm{C}$ for $24-48 \mathrm{hrs}$. Violet coloured colonies were counted and results were expressed as $\log \mathrm{cfu} / \mathrm{g}$.

\section{Enumeration of yeast and mould count:-}

Yeast and mould were counted by pour plating method on YGC agar, followed by incubation at $25^{\circ} \mathrm{C}$ for $3-5$ days. Colonies were counted and results were expressed as log cfu/g.

Identification of $E$. coli:-

E. coli was identified by using chorom agar ECC (trypton bile X-glucouronide agar) by incubation at $30^{\circ} \mathrm{C}$ and $44^{\circ} \mathrm{C}$ for $24 \mathrm{~h}$. The blue-green colonies were counted as E. coli. Isolated E. coli on chorom agar ECC was subcultured onto Cefixime - Tellurite Sorbitol Mac Conkey agar at $37^{\circ} \mathrm{C}$ for $24 \mathrm{~h}$. Colorless colonies on the CT-SMAC agar were tested for $E$. coli by latex agglutination test.

\section{Identification of Shigella spp.:-}

Transfer for a $5 \mathrm{~mm}$ loopful of enrichment broth culture to the surface of Mac Conkey agar and XLD agar plate and streak to obtain isolated colonies. Invert \& incubates plates at $35-37^{\circ} \mathrm{C}$ for $24 \pm 2 \mathrm{hr}$. typical Shigella colonies on XLD agar appear as red pink colonies usually about $1 \mathrm{~mm}$ in diameter and on mac conkey agar as opaque or transparent colonies. Incubate each suspected colony into TSI agar slant by streaking the slant and stabbing the butt. After overnight incubation at $35-37^{\circ} \mathrm{C}$, typical Shigella reaction is alkaline (red) slant \& aid (yellow) butt with no $\mathrm{H}_{2} \mathrm{~S}$ or gas production. Using sterile needle inoculate a portion of the presumptive positive culture on TSI slant into following broth. Incubate at $35^{\circ} \mathrm{C}$ for the specified period of days and read for salmonella typical reaction. Expression of results analyzed in present/absent per $25 \mathrm{gm}$.

\section{Identification of Salmonella spp.:-}

The blended samples in BPW were incubated at $37^{\circ} \mathrm{C}$ for $20-24 \mathrm{~h}$. Salmonella spp. was then enrichment in Rappaport - Vassiliadis enrichment broth (RVS) and tetrathionatbroth containing iodine solution and neobiocin (40 $\mu \mathrm{g} / \mathrm{ml}$ ) at $41.5^{\circ} \mathrm{C}$ for $24 \mathrm{~h}$. After $18-24 \mathrm{~h}$, samples then streaked on xylose lysine desoxycholate (XLD), Bismuth sulfite iron agar (BSI)and brilliant green agar (BGA) and incubated at $37^{\circ} \mathrm{C}$ for $24-48 \mathrm{~h}$. Two or more identical colonies were then transferred to lysine iron agar, triple sugar iron agar slants and urease broth. Each culture showing presumptive-positive results was maintained on Brain heart infusion agar. Cultures were further subjected to serological tests using polyvalent $\mathrm{O}$ and $\mathrm{H}$ antisera.

\section{Identification of Staphylococcus aureus:-}

Staphylococcus aureus was isolated and enumerated by pour plating onto Baird-Parker agar containing egg yolk emulsion and incubated at $35^{\circ} \mathrm{C}$ for $24 \mathrm{~h}$. Two or three of black colonies were selected and tested for catalase test, gram reaction and coagulase reaction. 


\section{Statistical analysis:-}

The data ascertained from the experiments on different parameter were subjected to statistical analysis using mean standard deviation, standard error and ANOVA Two way classification with $\mathrm{r}=3$ observation as per cell, if significant results were obtained due to places or types of vegetables, the value of C.D. was also calculated at 5\% level of significance, which was used for comparing all possible combination of two vegetables at a time two places together. Tabulation and graphical methods were also used to represent the obtained data.

\section{Results \& Discussions:-}

Table 1:- Total aerobic bacterial counts in samples of green leafy vegetables (log $\mathbf{~ f f u / g m . )}$

\begin{tabular}{|l|c|c|c|}
\hline \multirow{2}{*}{ Veg. } & $\begin{array}{c}\text { Soya leaves } \\
\text { (Log cfu/gm.) }\end{array}$ & $\begin{array}{c}\text { Fenugreek leaves } \\
\text { (Log cfu/gm.) }\end{array}$ & $\begin{array}{c}\text { Spinach } \\
\text { (Log cfu/gm.) }\end{array}$ \\
\cline { 2 - 4 } & Mean \pm SE & Mean \pm SE & Mean \pm SE \\
\hline Phaphamau & $5.31 \pm 0.15$ & $4.27 \pm 0.011$ & $5.36 \pm 0.054$ \\
\hline Mundera & $5.16 \pm 0.016$ & $4.53 \pm 0.0 .12$ & $6.64 \pm 0.032$ \\
\hline Naini & $7.6 \pm 0.46$ & $6.49 \pm 0.25$ & $8.5 \pm 0.26$ \\
\hline Jhunsi & $6.74 \pm 0.092$ & $4.53 \pm 0.28$ & $7.63 \pm 0.02$ \\
\hline Mean & 6.20 & 4.955 & 7.03 \\
\hline Control & $0.15 \pm 0.023$ & $0.2 \pm 0.023$ & $0.19 \pm 0.023$ \\
\hline
\end{tabular}

In this present study the above table reveals that the total aerobic bacterial count ranged in Soya leaves for all places were from $5.16 \pm 0.016$ to $7.6 \pm 0.46$, in Fenugreek leaves from $4.27 \pm 0.011$ to $6.49 \pm 0.25$ and in Spinach from $5.36 \pm 0.054$ to $8.5 \pm 0.26$. Highest bacterial counts were found in Spinach for Naini area while lowest was found in Soya leaves for Mundera area. Total bacterial counts trends in all the leafy vegetables for all places were as follows: Spinach (7.03) > Soya leaves (6.20) > Fenugreek leaves (4.955). In fresh water grown leafy vegetables the total aerobic bacterial counts were lower than sewage grown leafy vegetables, for Soya leaves, Fenugreek leaves and Spinach bacterial counts were $0.15 \pm 0.023,0.2 \pm 0.023$ and $0.19 \pm 0.023$ respectively.

The ANOVA skeleton revealed that the calculated value of $\mathrm{F}$ due to vegetables and due to places were greater than the tabulated value of $\mathrm{F}$ on 2 and $28 d . f$. and at $5 \%$ probability level; hence our null hypothesis was rejected. Therefore it can be concluded that there was significant difference between three vegetables and four places.

Since the ANOVA showed significant result due to vegetables so to compare all possible combination of two vegetables; the value of critical difference was calculated at $5 \%$ level of significance which was obtained as 0.01 hence the comparison table is appended below:

Table 1.1:- Comparison table for total aerobic bacterial count.

\begin{tabular}{|l|c|c|}
\hline & $\mathrm{V}_{3}=19.96$ & $\mathrm{~V}_{2}=28.036$ \\
\hline $\mathrm{V}_{1}=21.64$ & $6.39^{*}$ & $1.68^{*}$ \\
\hline $\mathrm{V}_{2}=19.96$ & $8.0 \%^{*}$ & - \\
\hline
\end{tabular}

From the above comparison table significant difference was observed between Soya leaves and Fenugreek leaves $\left(V_{1}\right.$ and $\left.V_{2}\right)$, Fenugreek leaves and Spinach $\left(V_{2} \& V_{3}\right)$ and between Soya leaves and Spinach $\left(V_{1} \& V_{3}\right)$. Since the average value of Fenugreek leaves $\left(\mathrm{V}_{2}\right)$ is smallest so it can be regarded as the best vegetable as regards to total aerobic bacterial count. The calculated mean in descending order for the vegetables was as follows: (V3) Spinach $(28.036)>\left(\mathrm{V}_{1}\right)$ Soya leaves $(21.64)>\left(\mathrm{V}_{2}\right)$ Fenugreek leaves (19.96).

Mohammad et al.,(2012) reported that the aerobic bacterial plate count were ranged from $4.1 \mathrm{log} \mathrm{cfu} / \mathrm{g}$ to $8.3 \log$ cfu/g in mixed fresh-cut salads and from $4.3 \mathrm{log} \mathrm{cfu} / \mathrm{g}$ to $8.3 \mathrm{log} \mathrm{cfu} / \mathrm{g}$ in mixed green leaves vegetables. The microbial load of $44.9 \%$ of mixed fresh-cut salads and $43.5 \%$ of mixed green leaves vegetables was in the range of 7 $\log \mathrm{cfu} / \mathrm{g}$ to $8 \log \mathrm{cfu} / \mathrm{gm}$.

Vegetable samples examined by Nguz et al.,(2005) Johnston et al.,(2005) and Seo et al.,(2010) reported the means of bacterial count ranged from 3.0 to $7.8 \mathrm{log} \mathrm{cfu} / \mathrm{gm}$. on restaurant prepared lettuce, 4.5 to $6.2 \mathrm{log} \mathrm{cfu} / \mathrm{gm}$. on fresh produces and $5.4 \mathrm{log} \mathrm{cfu} / \mathrm{gm}$. to $8.9 \mathrm{log} \mathrm{cfu} / \mathrm{g}$ in mixed salads. Studies of these results were almost in agreement with 
other researchers. According to Frank- Peterside and Waribor, (2006) bacterial load on leafy vegetables increases with time during storage. If the counts are high then they pose dangers to the consumers.

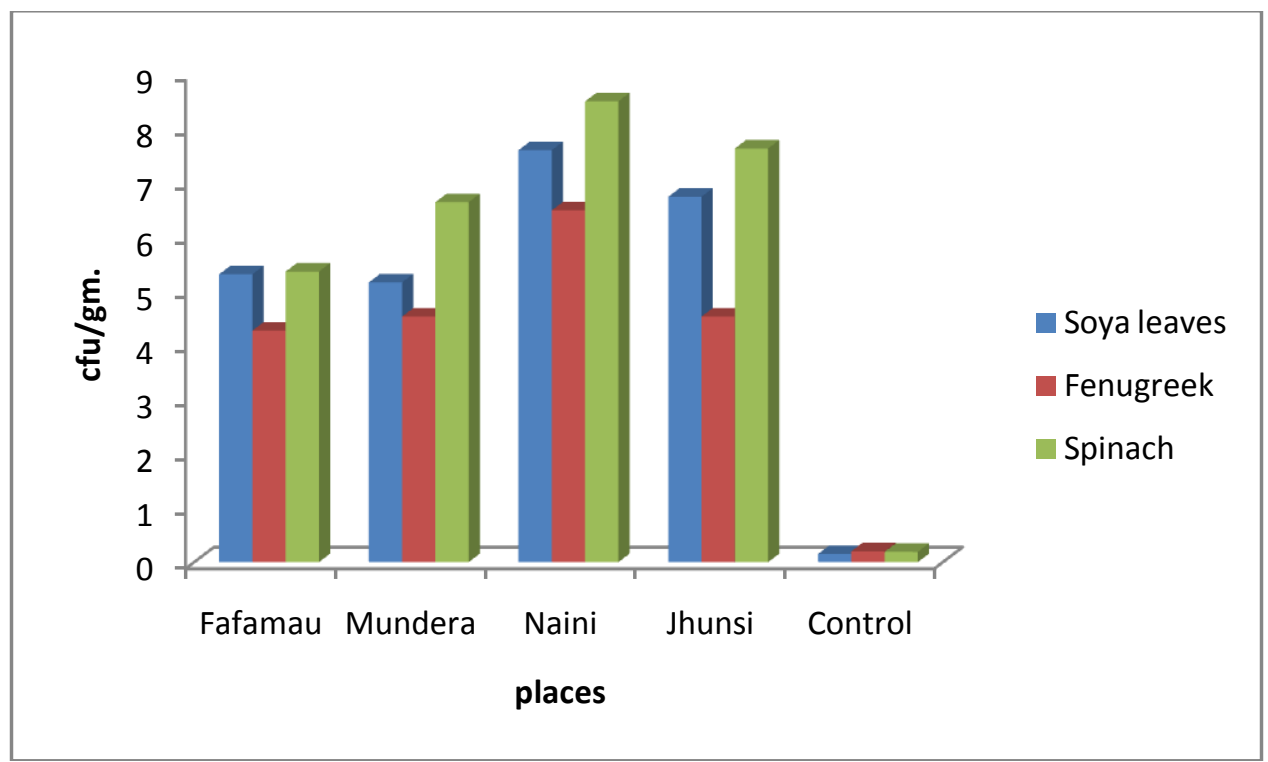

Figure 1:- Showing the total bacterial count in various leafy vegetables.

Table 2:- Total coliforms in leafy vegetables.

\begin{tabular}{|l|c|c|c|}
\hline \multirow{2}{*}{ Vegetables } & $\begin{array}{c}\text { Soya leaves } \\
\text { Places }\end{array}$ & $\begin{array}{c}\text { Fenugreek leaves } \\
\text { (Log cfu/gm.) }\end{array}$ & $\begin{array}{c}\text { Spinach } \\
\text { (Log cfu/gm.) }\end{array}$ \\
\cline { 2 - 4 } & Mean \pm SE & Mean \pm SE & Mean \pm SE \\
\hline Phaphamau & $1.3 \pm 0.12$ & $1.3 \pm 0.046$ & $2.6 \pm 0.13$ \\
\hline Mundera & $4.31 \pm 0.035$ & $3.55 \pm 0.036$ & $3.43 \pm 015$ \\
\hline Naini & $6.18 \pm 0.030$ & $4.69 \pm 0.11$ & $7.63 \pm 0.02$ \\
\hline Jhunsi & $4.68 \pm 0.039$ & $3.49 \pm 0.075$ & $4.28 \pm 0.044$ \\
\hline Mean & 4.11 & 3.25 & 4.485 \\
\hline Control & NIL & NIL & NIL \\
\hline
\end{tabular}

In this present study above table 2 reveals that the total coliform count ranged in Soya leaves for all places were from 1.3 \pm 0.12 to, $6.18 \pm 0.030$, in Fenugreek leaves from $1.3 \pm 0.046$ to $4.69 \pm 0.11$ and in Spinach from $2.6 \pm 0.13$ to7.63 \pm 0.02 . Highest bacterial counts were found in Spinach for Naini area while lowest was found in Soya leaves/dill for Phaphamau area. The averages total coliforms counts in all the leafy vegetables for all places were trends as follows: Spinach (4.485) > Soya leaves (4.11) > Fenugreek leaves (3.25). In fresh water grown leafy vegetables the total coliform count were not detected in any vegetables for any of the study sites.

The ANOVA skeleton revealed that the calculated value of $\mathrm{F}$ due to vegetables were greater than the tabulated value of $\mathrm{F}$ on 2 and $28 d . f$. and at 5\% probability level; hence our null hypothesis was rejected. Therefore it can be concluded that there was significant difference between three vegetables but the calculated value of $\mathrm{F}$ due to places were smaller than its table value at 5\% level of significance, concluding there by no significant difference between four places occurred.

Since the ANOVA showed significant result due to vegetables so to compare all possible combination of two vegetables; the value of critical difference was calculated at $5 \%$ level of significance which was obtained as 0.278 hence the comparison table is appended below:

Table 2.1:- Comparisons table for total coliform in leafy vegetables.

\begin{tabular}{|l|c|c|}
\hline & $\mathrm{V}_{3}=17.9$ & $\mathrm{~V}_{2}=13.04$ \\
\hline $\mathrm{V}_{1}=16.8$ & $1.1^{*}$ & $3.76^{*}$ \\
\hline $\mathrm{V}_{2}=13.04$ & $4.86^{*}$ & - \\
\hline
\end{tabular}


From the above comparison table significant difference was observed between Soya leaves and Fenugreek leaves $\left(\mathrm{V}_{1} \& \mathrm{~V}_{2}\right)$, Fenugreek leaves and Spinach $\left(\mathrm{V}_{2} \& \mathrm{~V}_{3}\right)$ \& between Soya leaves and Spinach $\left(\mathrm{V}_{1} \& \mathrm{~V}_{3}\right)$. Since the average value of Fenugreek leaves $\left(\mathrm{V}_{2}\right)$ is smallest so it can be regarded as the best vegetable as regards to total coliform. The calculated mean in descending order for the vegetables were as follows: $\left(\mathrm{V}_{3}\right)$ Spinach $(17.9)>\left(\mathrm{V}_{1}\right)$ Soya leaves (16.8) > $\left(\mathrm{V}_{2)}\right.$ Fenugreek leaves (13.04).

Mohammad et al., (2008) reported that the total coliforms were between $3.9 \mathrm{log} \mathrm{cfu} / \mathrm{gm}$. To $7.48 \mathrm{log} \mathrm{cfu} / \mathrm{gm}$. for mixed fresh-cut salads and $3.2 \log \mathrm{cfu} / \mathrm{gm}$. to $7 \mathrm{log} \mathrm{cfu} / \mathrm{gm}$ for mixed green leafy vegetables. $50.6 \%$ and $49.4 \%$ of all mixed fresh-cut salads and mixed green leafy vegetables fell in a range between $5 \mathrm{log} \mathrm{cfu} / \mathrm{gm}$. to $6 \log \mathrm{cfu} / \mathrm{gm}$. Johnston et al., (2005) showed that total coliforms ranged from 1 to $4.3 \mathrm{log} \mathrm{cfu} / \mathrm{gm}$. in green leafy vegetables and herbs. Little et al., (1999) reported the levels of total coliforms in fresh lettuce up to $5 \mathrm{log} \mathrm{cfu} / \mathrm{gm}$. and Seo et al., (2010) found the range of total coliforms in mixed salad vegetables were from $2.7 \log \mathrm{cfu} / \mathrm{gm}$. to $8.2 \mathrm{log} \mathrm{cfu} / \mathrm{gm}$.

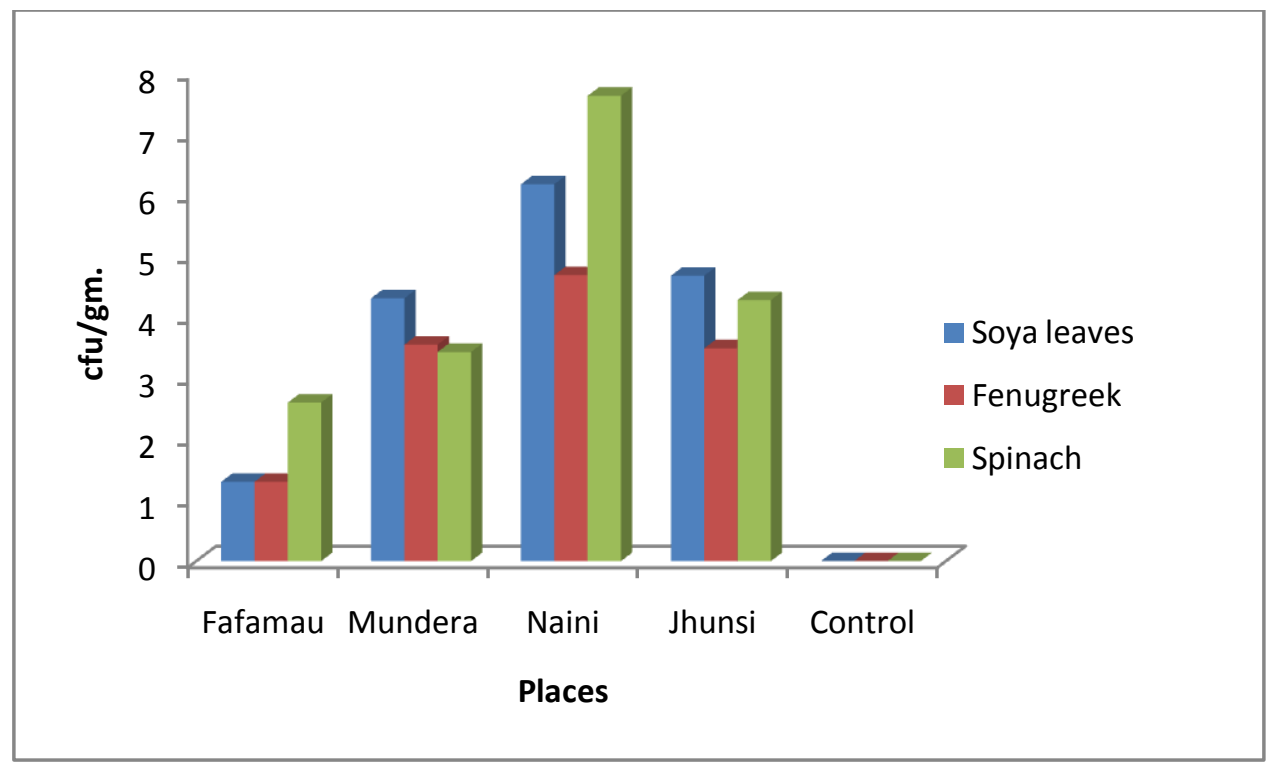

Figure 2:- Showing the total coliform in various leafy vegetables

Table 3:- Showing yeast and mould count in selected leafy vegetables (log cfu/g).

\begin{tabular}{|l|c|c|c|}
\hline \multirow{2}{*}{$\begin{array}{c}\text { Veg. } \\
\text { Places }\end{array}$} & $\begin{array}{c}\text { Soya leaves } \\
\text { (Log cfu/g.) }\end{array}$ & $\begin{array}{c}\text { Fenugreek leaves } \\
\text { (Log cfu/g) }\end{array}$ & $\begin{array}{c}\text { Spinach } \\
\text { (Log cfu/g) }\end{array}$ \\
\cline { 2 - 4 } & Mean \pm SE & Mean \pm SE & Mean \pm SE \\
\hline Phaphamau & $1.8 \pm 0.13$ & $2.83 \pm 0.13$ & $3.43 \pm 0.25$ \\
\hline Mundera & $1.7 \pm 0.23$ & $1.46 \pm 0.16$ & $4.36 \pm 0.23$ \\
\hline Naini & $3.1 \pm 0.13$ & $3.23 \pm 0.16$ & $3.46 \pm 0.19$ \\
\hline Jhunsi & $1.3 \pm 0.092$ & $1.66 \pm 0.069$ & $1.17 \pm 0.036$ \\
\hline Control & Nil & Nil & Nil \\
\hline
\end{tabular}

The above table 3 reveals that the total yeast and mould counts ranged in Soya leaves for all places were from $1.3 \pm 0.092$ to $1.8 \pm 0.13$ in Fenugreek leaves from $1.46 \pm 0.16$ to $3.23 \pm 0.16$ and in Spinach from $1.17 \pm 0.036$ to 4.36 \pm 0.23 . Highest yeast and mould counts were found in spinach for Mundera area while lowest count was found also in Spinach for Jhunsi area. Yeast and mould in all leafy vegetables for all places were trends as follows:Spinach (3.105) > Fenugreek leaves (2.995) > Soya leaves (1.975). In fresh water grown leafy vegetables the total yeast $\&$ mould count were not detected in any vegetables for any of the study sites.

The ANOVA skeleton revealed that the calculated value of $\mathrm{F}$ due to vegetables were greater than the tabulated value of $\mathrm{F}$ on 2 and $28 d . f$. and at $5 \%$ probability level; hence our null hypothesis was rejected. Therefore it can be concluded that there is significant difference between three vegetables and thereby that no significant difference between four places. 
Since the ANOVA showed significant result due to vegetables so to compare all possible combination of two vegetables; the value of critical difference was calculated at $5 \%$ level of significance which was obtained as 0.469 ; hence the comparison table is appended below:

Table 3.1:- Comparison table for yeast and mould count in leafy vegetables

\begin{tabular}{|l|c|c|}
\hline & $\mathrm{V}_{3}=12.44$ & $\mathrm{~V}_{2}=9.16$ \\
\hline $\mathrm{V}_{1}=7.96$ & $4.48^{*}$ & $1.2^{*}$ \\
\hline $\mathrm{V}_{2}=9.16$ & $3.28^{*}$ & - \\
\hline
\end{tabular}

From the above comparison table significant difference was observed between Soya leaves and Fenugreek leaves $\left(V_{1}\right.$ and $\left.V_{2}\right)$, Fenugreek leaves and Spinach $\left(V_{2}\right.$ and $\left.V_{3}\right)$ \& between Soya leaves and Spinach $\left(V_{1}\right.$ and $\left.V_{3}\right)$. Since the average value of Soya leaves $\left(\mathrm{V}_{1}\right)$ was smallest so it can be regarded as the best vegetable as regards to yeast \& mould count. The calculated mean in descending order for vegetables were as follows: - $\left(\mathrm{V}_{3}\right)$ Spinach $(12.44)>\left(\mathrm{V}_{2}\right)$ Fenugreek leaves $(9.16)>\left(\mathrm{V}_{1}\right)$ Soya leaves (7.96).

A similar study done by Mohammad et al.,(2008) reported that the yeasts and moulds count were between $3.85 \log$ cfu/gm. to $6.7 \mathrm{log}$ cfu/gm. leafy vegetable samples examined by Nguz et al.,(2005), Johnston et al., (2005) and Seo et al.,(2010) reported the means of yeast and mould ranged from 3.0 to $7.8 \log \mathrm{cfu} / \mathrm{gm}$., 4.5 to $6.2 \mathrm{log} \mathrm{cfu} / \mathrm{gm}$. on fresh produces and $5.4 \mathrm{log} \mathrm{cfu} / \mathrm{gm}$. to $8.9 \mathrm{log} \mathrm{cfu} / \mathrm{gm}$. in leafy vegetables.

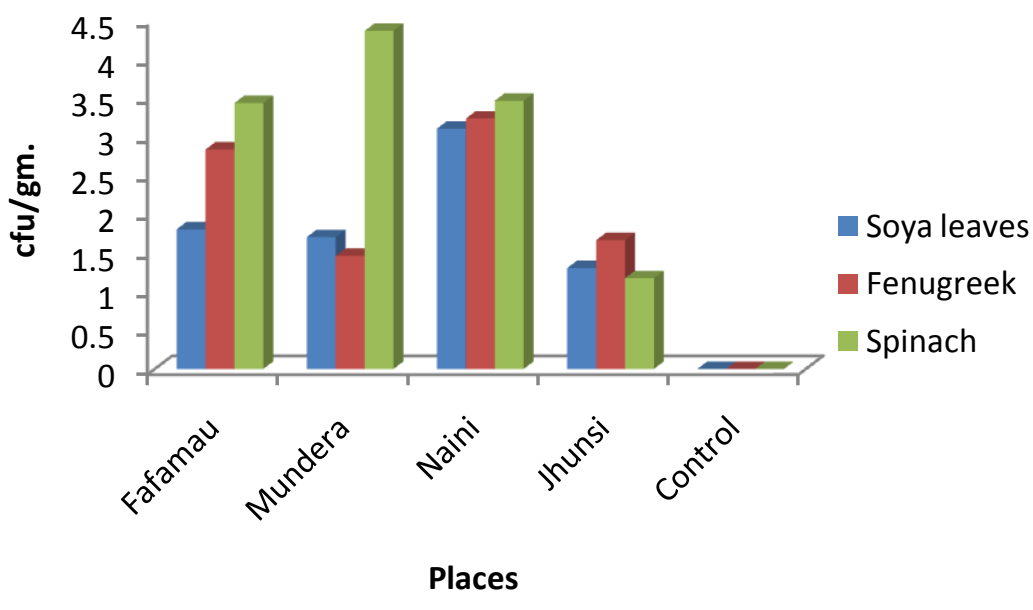

Figure 3:- Showing the yeast and mould count in various leafy vegetables.

Table 4:- Showing the presence / absence of microorganism in Soya leaves / Dill.

\begin{tabular}{|l|c|c|c|c|}
\hline \multirow{2}{*}{$\begin{array}{l}\text { MOS } \\
\text { Places }\end{array}$} & \multicolumn{3}{|c|}{ Presence / absence detected in samples of Soya leaves/25gm } \\
\cline { 2 - 5 } & E coli & $\begin{array}{l}\text { Shigella } \\
\text { spp. }\end{array}$ & $\begin{array}{l}\text { Salmonella } \\
\text { spp. }\end{array}$ & $\begin{array}{l}\text { Staphylococcus } \\
\text { aureus }\end{array}$ \\
\hline Phaphamau & - & + & - & - \\
\hline Mundera & - & + & - & - \\
\hline Naini & + & + & + & + \\
\hline Jhunsi & + & + & + & + \\
\hline Control & $\mathrm{ND}^{*}$ & $\mathrm{ND}^{*}$ & $\mathrm{ND}^{*}$ & $\mathrm{ND}^{*}$ \\
\hline
\end{tabular}

*Not detected

Table 5:- Showing presence / absence of microorganism in Fenugreek leaves.

\begin{tabular}{|l|c|c|c|c|}
\hline \multirow{2}{*}{$\begin{array}{c}\text { MOS } \\
\text { Places }\end{array}$} & \multicolumn{3}{|c|}{ Presence/absence detected in samples of Fenugreek leaves/25gm. } \\
\cline { 2 - 5 } & E. coli & $\begin{array}{l}\text { Shigella } \\
\text { spp. }\end{array}$ & $\begin{array}{l}\text { Salmonella } \\
\text { spp. }\end{array}$ & $\begin{array}{l}\text { Staphylococcus } \\
\text { aureus }\end{array}$ \\
\hline Phaphamau & - & + & - & + \\
\hline Mundera & - & + & + & - \\
\hline
\end{tabular}




\begin{tabular}{|l|c|c|c|c|}
\hline Naini & + & + & + & + \\
\hline Jhunsi & + & + & + & + \\
\hline Control & ND" & ND" & ND" & ND $^{*}$ \\
\hline
\end{tabular}

Not detected

Table 6:- Showing presence /absence of microorganism in Spinach.

\begin{tabular}{|l|c|c|c|c|}
\hline \multirow{2}{*}{$\begin{array}{c}\text { MOS } \\
\text { Places }\end{array}$} & \multicolumn{3}{|c|}{ Presence/absence detected in samples of Spinach/25gm. } \\
\cline { 2 - 5 } & E. coli & Shigella spp. & $\begin{array}{l}\text { Salmonella } \\
\text { spp. }\end{array}$ & $\begin{array}{l}\text { Staphylococcus } \\
\text { aureus }\end{array}$ \\
\hline Phaphamau & + & + & + & + \\
\hline Mundera & + & + & + & + \\
\hline Naini & + & + & + & + \\
\hline Jhunsi & + & + & $\mathrm{ND}^{*}$ & + \\
\hline Control & $\mathrm{ND}^{*}$ & $\mathrm{ND}$ & $\mathrm{ND}^{*}$ \\
\hline
\end{tabular}

*Not detected

Above mentioned table no. 4, 5 \& 6 shows that the presence of E. coli was identified in Soya leaves and Fenugreek leaves for Naini and Jhunsi area and in Spinach for all the study site whereas it was found to be absent for Phaphamau and Mundera area in Soya leaves and Fenugreek leaves. The presence of Shigella spp. was identified in all leafy vegetables for all the study sites. Salmonella spp. were present in Soya leaves for only Naini and Jhunsi area, in Fenugreek leaves its presence was isolated for all the study sites except Phaphamau but its presence in Spinach was identified for all the study sites. The presence of Staphylococcus aureus was identified in Soya leaves only for Naini and Jhunsi areas, in Fenugreek leaves for all the study sites except Mundera area while its presence was identified in Spinach for all the study sites. Presences of these microorganisms were not detected for control site where fresh ground water was used for irrigation of leafy vegetables.

Kim et al., (2008) demonstrated that the E. coli can be transferred to the vegetables even though iced water. Poorna et al., (2008) also showed the presence of Enterobacter, Staphylococcus aureus, E. coli and P. aeruginosa, Shigella spp. \& Salmonella spp. \& reported that these are a normal microbial flora of the mucus membrane and on the human skin. It is an opportunistic pathogen and enterotoxigenic strains which are known to cause serious food borne diseases and has been reported that ingestion of the thermo stable enterotoxins, rather than the bacterium itself is responsible for food borne illness. They cause boils, abscesses, post-operative infections, toxic shock syndrome and food poisoning in man.

\section{Conclusion:-}

The present study was aimed to enumerate the microbial load in leafy vegetables grown in periphery of Allahabad district where sewage water was used for watering the leafy vegetables. The results obtained have shown that the microorganisms were abundant in leafy vegetables \& there were the significant difference for both due to vegetables $\&$ due to places. The microbiological status of analyzed leafy vegetables was showed that the vegetables produced in sewage irrigated study sites represent a high microbiological risk for consumers in comparison to fresh ground water grown leafy vegetables where total aerobic bacterial count was low and presence of E. coli, Salmonella spp., Shigella spp. and Staphylococcus aureus were not found. It is therefore urgent to sensitize the vegetables growers and consumers about vegetable contamination problems. Further studies could be recommended to evaluate the development of resistance of the concerned microorganisms frequently identified on the vegetable. From the results obtained it was quite obvious that eating these vegetables can expose the consumer to a lot of health risks. Therefore it is recommended that these vegetables should be thoroughly washed before consumption especially where they are not going to be cooked before consumption.

\section{References:-}

1. Amitabha, R. 2005. Cancer selective role of selected dietary factors. India Journal of Cancer, Vol. 42 , Issue 1.

2. Adebooye, O. C. and Opabode, J. T. (2004). Status of conservation of the indigenous leaf vegetables and fruits of Africa. African Journal of Biotechnology 3: 700-705.

3. Alvaro, J. E., Moreno, S. Dianez, F., Santos, M., Carrasco, G. and Urrestarazu, M. (2009). Effects of peraceticacid disinfectant on the postharvest of some fresh vegetables. Journal of Food Engineering 95: 11-15. 
4. Aycicek, H., Oguz, U. and Karci, K. 2006. Determination of total aerobic and indicator bacteria on some raw eaten vegetables from wholesalers in Ankara, Turkey. International Journal of Hygiene and Environmental Health. 209: 197-201.

5. Bhagwat, A. A. (2004). Rapid detection of Salmonella from vegetable rinse-water using real-time PCR. Food Microbiology 21: 73-78.

6. David-Benz, H., Wade, I. and Egg, J. (2005). In stabilité des prix et information sur les marchéshorticoles au Sénégal: repenser les systèmesd'informationsur les marchésagricoles. In IRAD, INRAB, ISRA et CIRAD, Agriculture et Development Urban en Afrique de l'Ouest et du Centre - Recueil des résumés, Atelier International du 31 October au 3 November 2005, Palais des Congrès, Yaoundé, Camerou.

7. FAO. (2007). Analyze des risquesrelatifs à la security sanitaire des aliments: Guide à l'usage des autoritésnationals'responsible de la sécurité sanitaire des aliments. Etude FAO Alimentation et Nutrition 87, Rome 2007, ISBN 978-92-5-205604-1.

8. Frank-Peterside, $\mathrm{N}$ and Waribor, $\mathrm{O}$ (2006). Bacteria associated with spoilage of fluted pumpkins leaves and their effect on the chlorophyll content. Nigerian Journal of Microbiology. 20(1): 751 - 756,

9. Fonseca, J. M. (2006). Postharvest quality and microbial population of head lettuce as affected by moisture at harvest. Journal of Food Science 71:45-49.

10. Gil, M. I., Selma, M. V., López-Gálvez, F. and Allende, A. (2009). Fresh-cut product sanitation and wash water disinfection: Problems and solutions. International Journal of Food Microbiology 134: 37-45.

11. Heber, D.(2004). Vegetables, fruits and phytoestrogens in the prevention of diseases. Journal of Postgraduate Medicine 50: 145-149.

12. Idogun, E. S., Famodu, A. A., Olasunkanmi, L. A., Osilesi, O. and Adebawo, O.O. (2008). Effects of fruits and vegetables on electrolytes and blood pressure of hypertensive patients seen in Nigeria. African Journal of Food Agriculture and Nutrition Development 8 (3): 349-357.

13. Islam, M., M. P., Doyle, S. C., Phatak, P. Millner, and X. Jinag. (2004). A Persistence of Enter hemorrhagic Escherichia coli 0157:H7 in soil and on leaf lettuce and parsely grown fields treated with contaminated manure composts and irrigation water. Journal of Food Protection, 67:1365-1370.

14. Johnston, L.M., Jaykus, L., Moll, D., Martinez, M.C., Anciso, J., Mora, B. and Moe, C.L., (2005). A field study on the microbiological quality of fresh produce. Journal of Food Protection. 68: 1840-1847.

15. Kim, J.K and Harrison, M.A (2008). Transfer of E, coli0157:H7 to Romaine lettuce due to contact water from melting ice. Journal of Food protection 71 (2): 252- 256.

16. Little, C.L., Roberts, D., Youngs, E., and de Louvouis, J., (1999). Microbiological quality of retail importedunprepared whole lettuce. A PHLS food working group study. Journal of Food Protection. 62: 325328.

17. McMahon, M. A. S. and Wilson, I. G. 2001. The occurrence of enteric pathogens and Aeromonas species inorganic vegetables. International Journal of Food Microbiology 70: 155-162.

18. Muhammad, F., Farooq, A. and Umer, R., (2008) Appraisal of heavy metal contents in different vegetables grown in the vicinity of an industrial area, Pakistan Journal of Botany, 40(5): 2099-2106.

19. Nguz, K., Shindano, J., Samapundo, S., and Huyghebaert, A., (2005). Microbiological evaluation of fresh-cut vegetables produced in Zambia. Food Control. 16: 623-628.

20. Pollard, C., Miller, M., Woodman, R. J., Meng, R. and Binns, C. (2009). Changes in Knowledge, Beliefs, and Behaviors Related to Fruit and Vegetable Consumption Among Western Australian Adults from 1995 to 2004. American Journal of Public Health, Vol 99. No. 2.

21. Ragaert, P., Verbeke, W., Devlieghere, F. and Debevere J. (2004). Consumer perception and choice of minimally processed vegetables and packaged fruits. Food Quality and Preference, 15: 259-270.

22. Schilter, C. (1991). L'agricultureurbaine à Lomé. Editions Karthalaet I.U.E.D. 22-24 Boulevard Arago, Paris, 24 rue Rothschild Genève 21, 335p.

23. Seo, Y. H., Jang, J. H., and Moon, K. W. (2010). Microbial evaluation of minimally processed vegetables and sprouts produced in Seoul, Korea. Food Science Biotechnology, 19 (5), 1283-1288.

24. Steele, M., and J. Odumeru. (2004). Irrigation water as a source of food borne pathogens on fruits and vegetables. Journal of Food Protection, 67:2839-2849.

25. Stine, S. W., I. Song. C. Y., Chio, and C. P., Gerba (2005). Application of microbial risk assessment to the development of standards for enteric pathogens in water used to irrigate fresh produce. Journal of Food Protection, 68:913-918.

26. Temple, R., Minkoua, R., Nkendah, R. and Marquis, S. (2005). Impact de l'urbanisationsurintensification des systèmes de production horticoles au Cameroun. In Atelier international sur agriculture etdevelopmenturban en Africa de l'Ouestet Centre, 31 oct au 3 nov 2005. 